\title{
THE MAPPING OF RASTER IMAGES ON PLANE ISOMETRIC GRID
}

\author{
A. Nesvidomin, Candidate of Technical Sciences, Associate Professor
}

\author{
A. Nesvidomina, engineer \\ National University of Life and Environmental Sciences of Ukraine
}

E-mail:a.nesvidomin@gmail.com

\begin{abstract}
Drawing images on curvilinear shapes with the least distortion takes place in many design tasks. In most ways, build a grid, each elementary cell of which is painted a given color. In this problem it is necessary to solve two main problems: the first - to carry out the formation of a given curvilinear grid with elementary cells in the form of squares, which are called isometric (or isothermal); the second is to paint each cell of the curved area with the corresponding pixel color of the original raster

The aim of the study is to reveal the way of displaying raster images on flat curvilinear areas represented by isometric grids, and with the help of a computer model in the Maple symbolic algebra to analyze the influence of isometric grid parameters on the position and size of displayed raster images.

The mapping of images onto curvilinear forms with minimal distortion takes place in many design tasks. A method of conformal mapping of arbitrary raster images onto plane curvilinear region is proposed, which are represented by isometric (also called isothermal) grids. The essence of the proposed method is as follows. Any raster image, for example, digital photography in jpg format, is characterized by the dimensions $N \times M$ - the number of pixels in width and height. In addition, each pixel has a color and brightness, which are arranged in rows and columns. To apply a raster image to a curvilinear region, it is also necessary to divide the curvilinear domain into $N \times M$, the number of elementary squares, each of which is assigned the corresponding color from the raster.
\end{abstract}

The influence $u=\left[u_{1} . u_{2}\right]$ and $v=\left[v_{1} . . v_{2}\right]$ arguments of the various isometric grids $R(u, v)$ constructed on the sizes and positions of an arbitrary raster image are investigated in the article. It is shown how the isometric grid, depending on $u$ and $v$ localizes the raster image - it can be located both within the limits of the isometric grid coordinate lines and beyond it, can also be oriented in different directions with respect to the $u$ and $v$ coordinate lines. It is shown the possibility of scaling a raster image that can be performed relative to the relative dimensions of an isometric grid. Since there is a correspondence between the pixel matrix of the original raster image and the $u, v$-cells of the isometric grid, the rotation of the image will affect its position in the isometric grid. For example, rotating the original bitmap image at an angle 90 degrees will change its location on a plane isometric grids -from along the u coordinate lines to along the $v$ coordinate lines. Note that, the curvilinear cells of the constructed isometric grids differ somewhat from the shape of the squares because the values $d u$ and $d v$ of the corresponding arguments $u$ and $v$ of their coordinate lines were taken somewhat too large. Otherwise, 
"Енергетика і автоматика", №1, 2021 р. cells would degenerate into points and the corresponding grid image would not be so clear.

\section{Key words: plane isometric grid, raster image, pixel color}

Introduction. Drawing images on curvilinear shapes with the least distortion takes place in many design problems [2]. In most ways you need to build a grid, each elementary cell of which is painted a given color. If any photographic image, as the original raster of $\mathrm{N} \times \mathrm{M}$ pixels is considered as squares of a certain color, then it is necessary to divide the curvilinear area into elementary squares, each of which is assigned a corresponding color from the raster. Thus, in this problem it is necessary to solve two main problems: the first - to carry out the formation of a given curvilinear grid with elementary cells in the form of squares, which are called isometric (or isothermal); the second is to paint each cell of the curved area with the corresponding pixel color of the original raster.

Analysis of recent researches and publications. The formation of flat isometric grids using a complex variable is shown in [3]. Drawing of images on isometric grids is given in [2].

The purpose of the study is to reveal a way to display raster images on flat curved areas represented by isometric grids. Using the developed computer model in the environment of symbolic algebra Maple [1] to analyze the influence of isometric grid parameters on the position and size of the displayed raster images.

Materials and methods. The general scheme of display of raster images on isometric grids is shown in Fig.1. The implementation of this scheme is possible only with the involvement of modern computer technology. We used the Maple computer algebra system [1].

Results and discussion. Let's have any bitmap image, such as a digital photo in jpg format. Raster image is characterized by size - the number of pixels in width and height. Each pixel has color and brightness. All this data is organized into rows and columns. To apply a raster image to a curved area, it is necessary to prepare it - scale, rotate, crop, etc. These operations in the Maple environment are performed by operators of the powerful 
"Енергетика і автоматика", №1, 2021 р.

ImageTools library [1]. The formation of flat isometric grids is carried out with the help of the library of functions of designing isometric grids developed by us under different initial conditions [3].
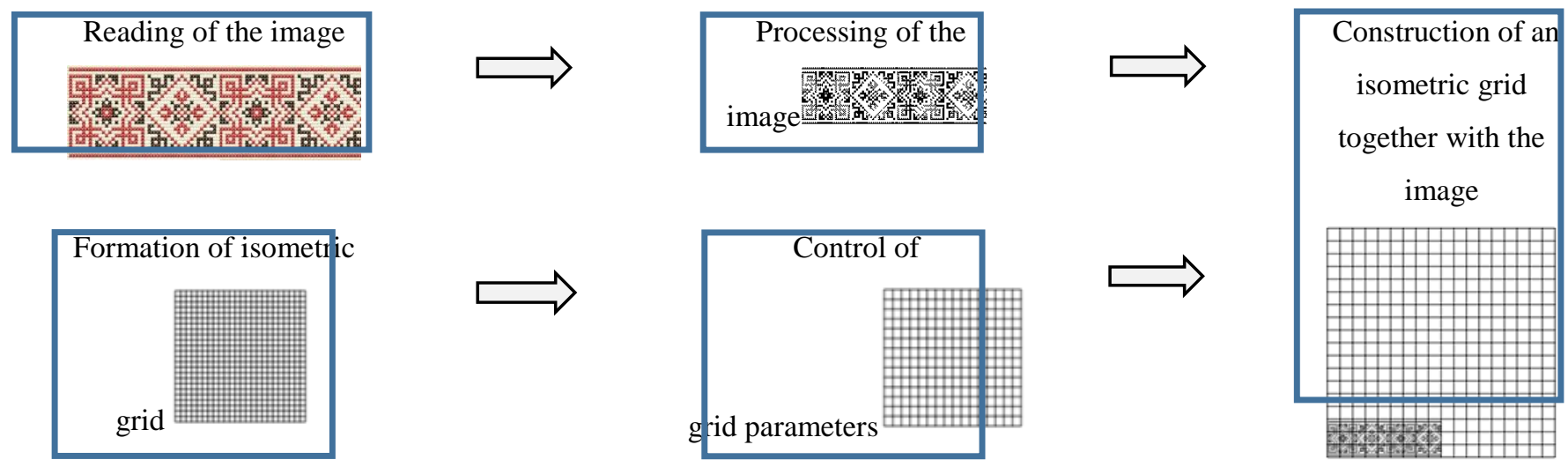

Fig. 1. The scheme of display of raster images on isometric grids

Take a parabolic isometric grid (Fig. 2, a), the parametric equation of which has the form:

$$
R(u, v)=R\left[u^{2}-v^{2}, 2 u v, 0\right],
$$

where $u=\left[u_{1} . u_{2}\right]$ and $v=\left[v_{1} . . v_{2}\right]-$ the arguments of the isometric grid are equal to $u=[-1 . .1]$

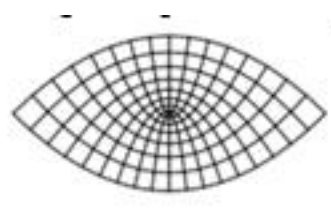

$a$
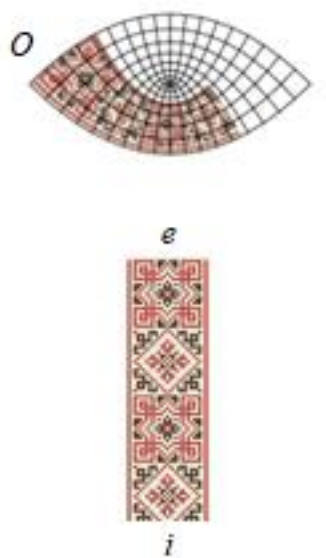

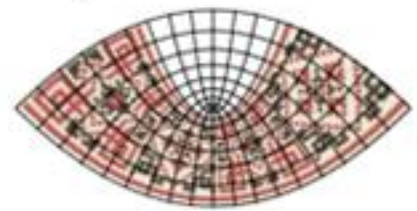

$b$

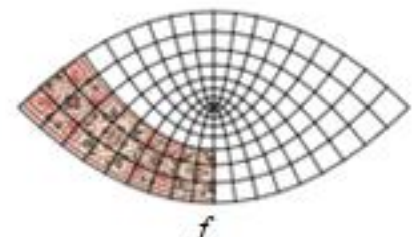

$f$

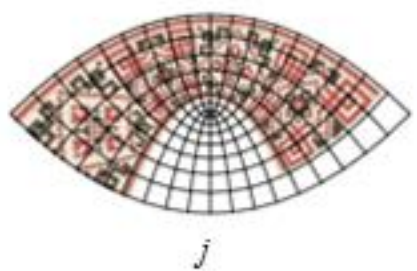

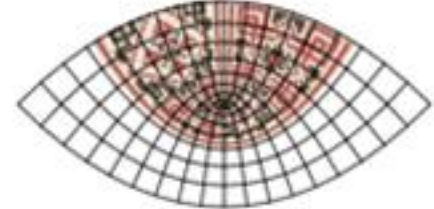

c

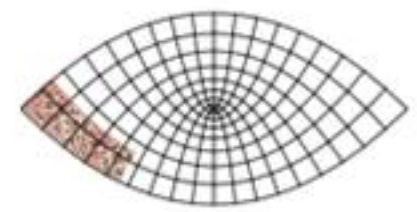

$g$

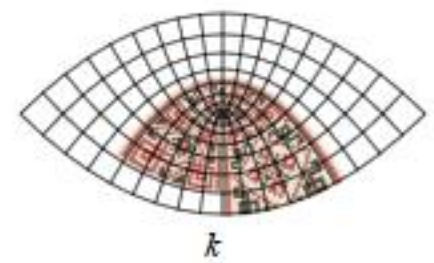

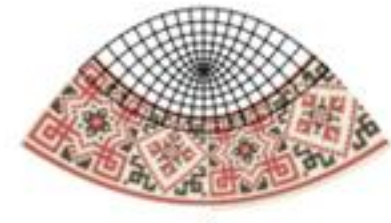

d
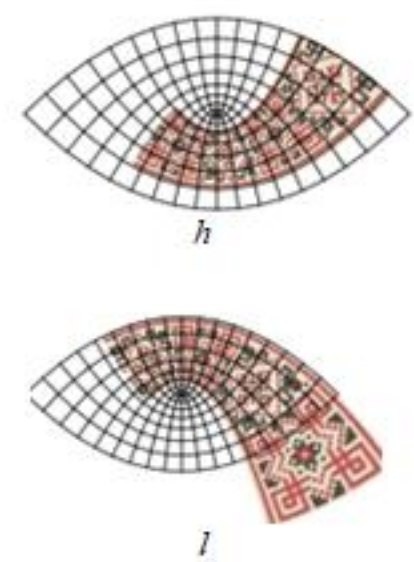

Fig. 2. Examples of drawing raster images on a parabolic isometric grid 
"Енергетика і автоматика", №1, 2021 р.

Equation (1) of the parabolic isometric grid was obtained by separating the real and imaginary parts $R[\operatorname{Re}(f), \operatorname{Im}(f), 0]$ of the quadratic function of a complex variable $f(z)=z^{2}$, where $z=u+v \sqrt{-1}$. The coefficients $E$ and $G$ the linear element $d s^{2}=E d u^{2}+2 F d u d v+G d v^{2}$ of the grid (1) are equal to each other $E=G=4$, and the coefficient $F=0$, confirming its isometricity.

Control of the position of the raster image and its size is carried out through the appropriate parameters of the developed model. Fig.2, b illustrates a raster image superimposed on an isometric grid, if the parameters of its position are taken $u_{o}=0, v_{o}=0$. If you take the value $v_{o}=1$, the raster image will be shifted along the $v$ coordinate line of the grid (Fig. 2, c). The raster image can lie outside the image of the isometric grid, as we have in the value $v_{o}=-0.5$ (Fig.2, d).

Implemented the possibility of scaling the raster, which can be done in relation to the relative dimensions of the isometric grid (1). Thus, Fig. 2, e, f, g, also illustrates similar raster images with similarity coefficients equal to $0.75,0.5$ and 0.25 . The center of similarity in the curvilinear coordinate system, which in this case is a parabolic isometric grid (1), is located at the point $\mathrm{O}$ - at the beginning of the $u, v$ coordinate lines. Simultaneously setting the similarity coefficient equal to the value of 0.75 and the parameters of the raster position $u_{o}=0.5, v_{o}=0.1$, you can place it in a given place of the isometric grid (Fig. 2, h).

Since there is a correspondence between the pixel matrix of the original raster image and the cells of the isometric grid $u, v$, the rotation of the image will affect its position in the isometric grid. Thus, rotating the original raster image at an angle of 90 degrees (Fig. 2 , i) will lead to the fact that for this image the number of pixels in height will be greater than in latitude. Reproduction of the rotated raster image shows its location along the grid line $v$ (Fig. 2, j). In Fig.2, k, 1 built raster images, respectively, for the parameters of position $u_{o}=0.5, v_{o}=0$ and $u_{o}=0, v_{o}=0.5$.

Let us investigate the influence of the arguments $u, v$-of the coordinate lines of the isometric grid on the display of raster images. To do this, take another isometric grid (Fig. 3 , a) with a parametric equation of the form: 


$$
R(u, v)=R[\sin (u) \cos (v), \cos (u) \sinh (v), 0],
$$

which was obtained by separating the real and imaginary parts $R[\operatorname{Re}(f), \operatorname{Im}(f), 0]$ of the sinusoidal function of a complex variable $f(z)=\sin (z)$.

If we accept the limits of change of arguments $u=[-1 . .1]$ and $v=[-1 . .1]$ of isometric grid (2) and display the original raster image (Fig. 3, b) with the values of the parameters of its position equal $u_{o}=0, v_{o}=0$, we obtain Fig. 3, c. We set other limits for changing the arguments $u=[-1 . .1]$ and $v=[0 . .1]$ for constructing an isometric grid (2). The display of the raster image on this grid leads to the fact that it is already in its upper part (Fig. 3, d). Fig.3, d shows the influence of the values of the limits of change of arguments $u=[-1 . .1]$ and $v=[-1 . .0]$ of isometric grid (2) on the display of the raster image. Fig.3, f, g, h, show the display of the raster image on the $1 / 4$ part of the isometric grid (2). 幽

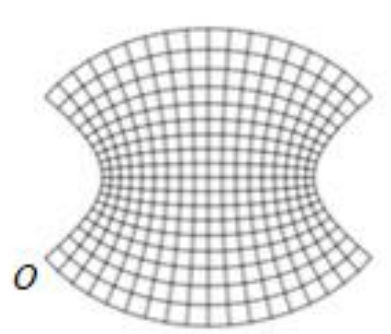

$a$

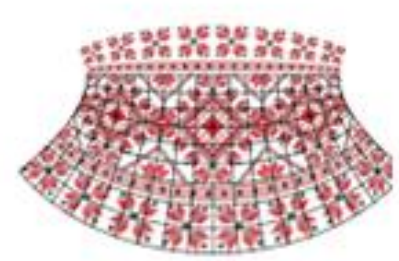

$u=[-1 . .1]$,

$v=[-1 . .0]$

e

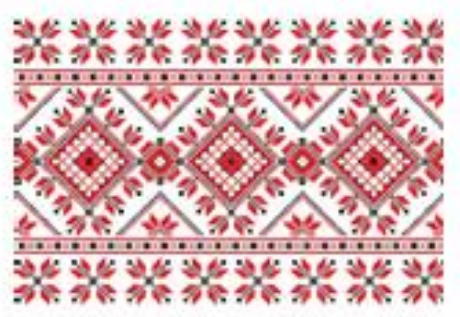

$b$

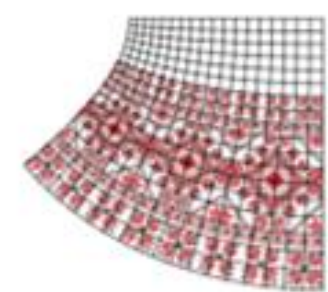

$u=[-1 . .0]$,

$v=[-1 . .0]$

$f$

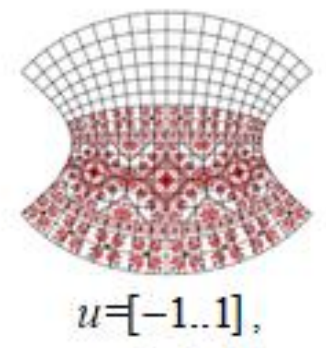

$v=[-1 . .1]$

c

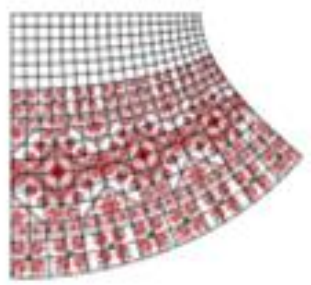

$u=[0 . .1]$,

$v=[-1 . .0]$

$g$

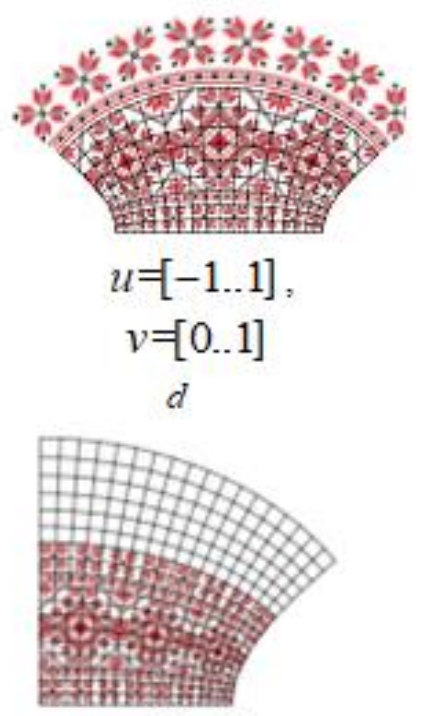

$u=[0 . .1]$,

$v=[0 . .1]$

$h$

Fig. 3. The influence of the arguments of the coordinate lines of the isometric grid on the size and position of the displayed raster image

The influence of arguments $u, v$ - -coordinate lines on raster images will be demonstrated using an isometric grid (Fig. 4, a), which is obtained by separating the real and imaginary parts $R[\operatorname{Re}(f), \operatorname{Im}(f), 0]$ of the function of a complex 
"Енергетика і автоматика", №1, 2021 р.

variable $f(z)=\sin (z)+\tan (z)$. The parametric equation of this isometric grid is quite cumbersome and therefore is not given here.

All construction of raster images were performed for the same argument values $u=[-1 . .1]$, but for different change limits of argument $v$. The position parameters of the raster image are equal $u_{o}=0$ and $v_{o}=0$. You can see (Fig. 4) how the isometric grid, depending on the $v=\left[v_{1} . . v_{2}\right]$ localization of the raster image - it does not go beyond the coordinate lines $u=[-1 . .1]$ of the isometric grid, but can be extended both up and down.

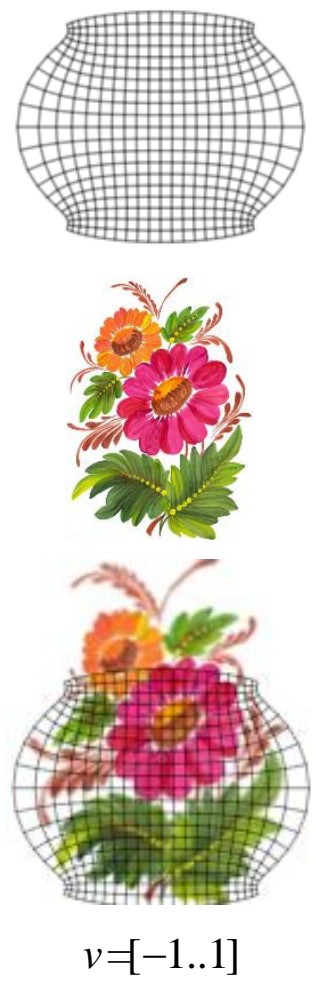

a
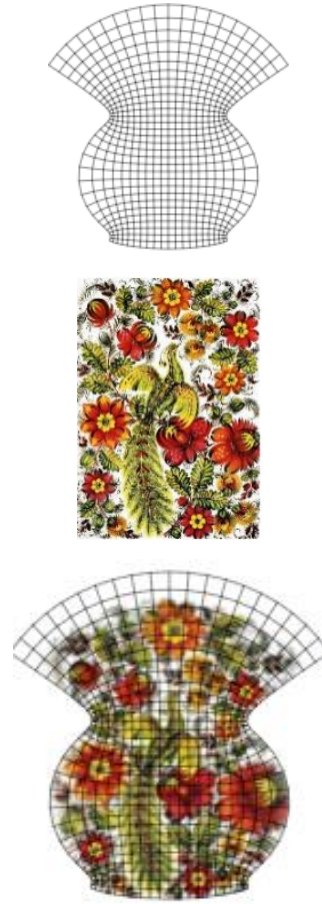

$v=[-1 . .2]$

$\mathrm{b}$
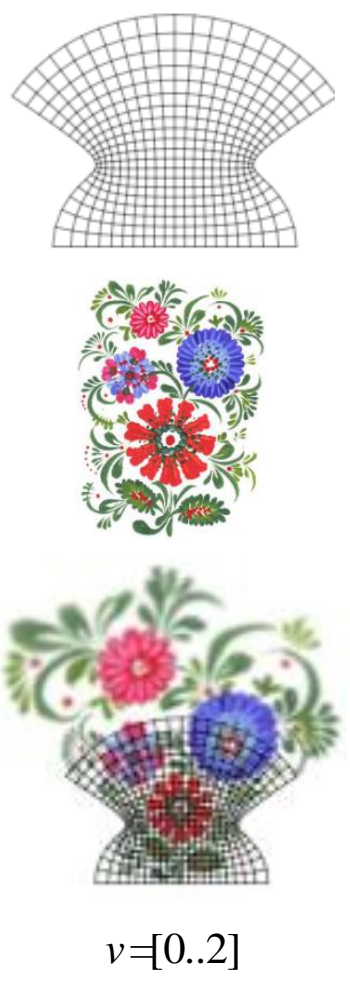

c
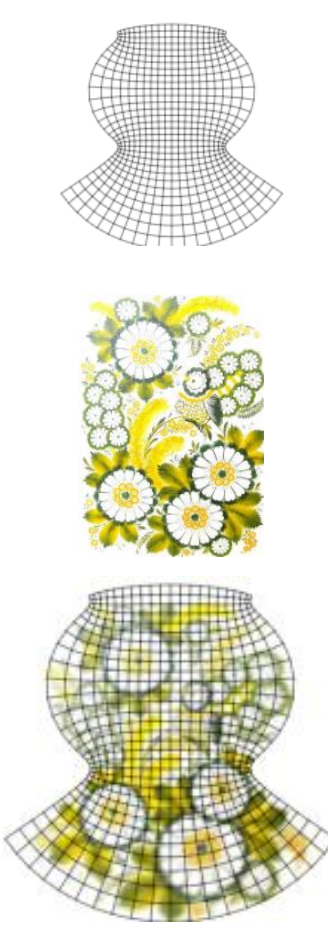

$v=[-2 . .1]$

d

Fig. 4. Examples of the interdependence between the isometric grid and the raster image applied to it

In the constructed images we will pay attention to two circumstances. First, all raster images were reproduced together with the isometric grid so that its effect on the change in image shape could be visually assessed. The second, curvilinear cells of the constructed isometric grids are slightly different from the shape of curvilinear squares, although the coefficients $E$ and $G$ the 1st quadratic shape of the grid are equal to each other. This is due to the fact that in order to improve the visualization of isometric grids, the values $d u$ and 
"Енергетика і автоматика", №1, 2021 р.

$d v$ the corresponding arguments $u$ and $v$ their coordinate lines were taken a little too large, otherwise the grid cells would degenerate into dots and get one shaded area.

Results and discussion. The proposed method of applying raster images on curved flat areas represented by isometric grids is characterized by the possibility, firstly, the implementation of conformal mapping, and secondly, the control of the location and scaling of the raster image through the appropriate parameters of the isometric grid.

\section{References}

1. Alad'yev, V. Z., Boyko, V. K., Rovba, E. A. (2007). Programmirovaniye i razrabotka prilozheniy v Maple [Programming and Application Development in Maple]. Grodno-Tallin, 458.

2. Kremets, T. S., Nesvidomin, V. M., Pylypaka, S. F. (2013). Peretvorennia ploskykh zobrazhen shliakhom nanesennia yikh na rizni izometrychni [Convert flat images by applying them to different isometric]. Pratsi Tavriiskoho derzhavnoho ahrotekhnolohichnoho universytetu. Prykladna heom. ta inzh. hraf., 4 (56), 158-163.

3. Nesvidomina, O. V. (2017). Pobudova ploskykh izometrychnykh sitok za napered zadanymy ploskymy kryvymy [Construction of flat isometric grids according to predefined flat curves]. Visnyk Khersonskoho natsionalnoho tekhnichnoho universytetu, 3 (620), V. 2, 196-199.

\section{Список використаної літератури}

1. Аладьев В. 3., Бойко В. К., Ровба Е. А. Программирование и разработка приложений в Maple. Гродно-Таллин, 2007. 458 с.

2. Кремець Т. С., Несвідомін В. М., Пилипака С. Ф. Перетворення плоских зображень шляхом нанесення їх на різні ізометричні. Праці Таврійського державного агротехнологічного університету. Прикладна геом. та інж. граф. 2013. Вип. 4. Т. 56. С. 158-163.

3. Несвідоміна О. В. Побудова плоских ізометричних сіток за наперед заданими плоскими кривими. Вісник Херсонського національного технічного університету. 2017. Вип.3 (620). Т.2. С. 196-199.

\section{ВІДОБРАЖЕННЯ РАСТРОВИХ ЗОБРАЖЕНЬ НА ПЛОСКІ ІЗОМЕТРИЧНІ СІТКИ}

\section{А. В. Несвідомін, О. В. Несвідоміна}

Анотація. Нанесення зображень на криволінійні форми з щонайменшими спотвореннями має місие в багатьох дизайнерських задачах. У більшості способів будують сітку, кожну елементарну чарунку якої зафарбовують заданим кольором. У поставленій проблемі необхідно вирішити дві основні задачі: перша - здійснити формування заданої криволінійної сітки з елементарними комірками у вигляді квадратів, які називають ізометричні (або ще ізотермічні); друга - зафарбувати 
"Енергетика і автоматика", №1, 2021 р.

кожну комірку криволінійної області відповідним кольором пікселя вихідного растра

Мета дослідження - розкрити спосіб відображення растрових зображень на плоскі криволінійні області, які представляються ізометричними сітками, та за допомогою розробленої комп'ютерної моделі в середовищу символьної алгебри Марle проаналізувати вплив параметрів ізометричної сітки на положення та розміри відображених растрових зображень.

Запропоновано метод конформного відображення довільних растрових зображень на площчину криволінійної області, які представлені ізометричними (їх також називають ізотермічними) сітками. Суть запропонованого способу полягає в такому. Будь-яке растрове зображення, наприклад, ичифрова фотографія у форматі jpg, характеризується розмірами $N \times M$ - кількістю пікселів по ширині та висоті. Крім того, кожен піксель має колір і яскравість, які розташовані в рядки $i$ стовпці. Щоб застосувати растрове зображення до криволінійної області, також необхідно розділити криволінійну область на $N \times M$, кількість елементарних квадратів, кожному з яких присвоєно відповідний колір із растру.

У статті досліджено вплив $u=\left[u_{1} . u_{2}\right]$ ma $v=\left[v_{1} . v_{2}\right]$ аргументів різних ізометричних сіток $R(u, v)$, побудованих за розмірами та положенням довільного растрового зображення. Показано, як ізометрична сітка, залежно від $u$ i локалізує растрове зображення - вона може розташовуватися як в межах координатних ліній ізометричної сітки, так $i$ за ї̈ межами, а також може бути орієнтована в різних напрямках щодо і координатних ліній. Показано можливість масштабування растрового зображення, яке можна виконати щуодо відносних розмірів ізометричної сітки. Оскільки існує відповідність між піксельною матрицеюю вихідного растрового зображення та u, v - клітинками ізометричної сітки, поворот зображення вплине на його положення в ізометричній сітиі. Наприклад, поворот вихідного растрового зображення на кут 90 градусів призведе до того, щзо для даного зображення кількість пікселів по висоті буде більшою чим по широті. Зауважимо, щуо криволінійні комірки побудованих ізометричних сіток дещьо відрізняються від форми квадратів, оскільки значення та відповідні аргументи та їх координатні лінії були прийняті дещьо занадто великими. В іншому випадку клітини вироджуються в точки, $i$ відповідне зображення сітки не буде настільки чітким.

\section{Ключові слова: плоска ізометрична сітка, растрове зображсення, колір пікселя}

\section{ОТОБРАЖЕНИЕ РАСТРОВЫХ ИЗОБРАЖЕНИЙ НА ПЛОСКИЕ ИЗОМЕТРИЧЕСКИЕ СЕТКИ}

\section{А. В. Несвидомин, А. В. Несвидомина}

Аннотация. Нанесение изображений на криволинейные формыл с малейшими искажениями имеет место во многих дизайнерских задачах. В больиинстве способов строят сетку, каждую элементарную ячейку которой закрашивают заданным цвветом. В поставленной проблеме необходимо решить две основные задачи: первая - осущуествить формирование заданной криволинейной сетки с элементарными ячейками в виде квадратов, которые называют изометрическими 
"Енергетика і автоматика", №1, 2021 р.

(или ещуе изотермическими), вторая - закрасить каждую ячейку криволинейной области соответствующчм цзветом пикселя исходного растра

Цель исследования - раскрыть способ отображения растровых изображений на плоские криволинейные области, которые представляются изометрическими сетками, и с помощьью разработанной компьютерной модели в среде символьной алгебры Maple проанализировать влияние параметров изометрической сетки на положение и размеры отраженных растровых изображений.

Предложен метод конформного отображения произвольных растровых изображений на плоскость криволинейной области, которые представлены изометрическими (их также называют изотермическими) сетками. Суть предлагаемого способа заключается в следующем. Любое растровое изображение, например, ичффровая фотография в формате jpg, характеризуется размерами $N \times$ M - количеством пикселей по ширине и высоте. Кроме того, каждый пиксель имеет извет и яркость, которые расположены в строки и столбцьь. Чтобы применить растровое изображение в криволинейной области, также необходимо разделить криволинейную область на $N \times M$ количество элементарных квадратов, каждый из которых присвоен соответствующий извет с растра.

В статье исследовано влияние $u=\left[u_{1} . u_{2}\right] u \quad v=\left[v_{1} . . v_{2}\right]$ аргументов различных изометрических сетей, построенных по размерам и положением произвольного растрового изображения. Показано, как изометрическая сетка, в зависимости от $u$ u л локализует растровое изображение она может располагаться как в пределах координатных линий изометрической сетки, так и за ее пределами, а также может быть ориентирована в различных направлениях и по координатным линиям. Показана возможность масштабирования растрового изображения, которое возможно выполнить относительно размеров изометрической сетки. Поскольку существует соответствие между пиксельной матрицей исходного растрового изображения $u$ u, v - клеточками изометрической сетки, поворот изображения повлияет на его положение в изометрической сетке. Например, поворот выходного растрового изображения на угол 90 градусов приведет к тому, что для данного изображения количество пикселей по высоте будет больше, чем по иироте. Заметим, что криволинейные ячейки построенных изометрических сеток несколько отличаются от формы квадратов, поскольку значения $и$ соответствующие аргументы и их координатные линии были приняты несколько больиими. В противном случае клетки вырождаются в точки, и соответствуюшее изображение сетки не будет столь четким.

Ключевые слова: плоская изометрическая сетка, растровое изображение, цвет пикселя 